\title{
The Wage Gap for Women Homeworkers and Their Role in Family Resilience
}

\author{
Intan Fatma Dewi ${ }^{1}$, Fentiny Nugroho ${ }^{2}$ \\ \{intanfatmadewi@gmail.com ${ }^{1}$, fentiny2015@gmail.com $\left.{ }^{2}\right\}$ \\ ${ }^{1,2}$ Postgraduate Program in Social Welfare, Faculty of Social and Political Sciences, Universitas \\ Indonesia
}

\begin{abstract}
The informal sector is always identified with the use of cheap labor. Especially labor-intensive industries, the use of cheap labor is also used as a strategy to reduce production costs. Homework with the putting-out scheme is one of them. Women homeworkers must work without a work agreement, clear working hours and very little wages. The existence of a wage gap between intermediaries and homeworkers is a problem that is quite complicated to resolve. Women homeworkers play a dual role in their families. In addition to having to do domestic work, women homeworkers also have to do productive work to get additional income for their domestic life.
\end{abstract}

Keywords: women homeworker, wage gap, gender, family.

\section{Introduction}

The informal sector is an important part of the economy that affects the labor market. In many countries, the informal sector plays a role in creating employment, production, and income. In countries with high population growth rates such as Indonesia, the informal sector tends to absorb most of the workforce in urban areas. As of February 2018, the number of unemployed has decreased to 140,000 or decreased by $5.13 \%$ of the total open unemployment rate [1].

The informal sector is always to be defined by the use of cheap labor. Especially in the labor-intensive industry, the use of cheap labor is also used as a strategy to lower production costs. Because the only cost can be relatively reduced to a minimum to produce a cheap product is the wages of workers. One of the schemes used in suppressing wage workers is the system's putting-out scheme.

The Homework Convention defines the putting-out system as a working system for which most of the production process is outside the company or in a home or self-selected place by its employees without supervision from employers [2]. The scheme's organized by agents or miners working on behalf of the company to employ a group of mothers in their homes, which are commonly referred to as home workers [3].

Homeworkers are dominated by women because the work in this sector has the flexibility of the labor market. So it becomes a profitable opportunity for those who do not have the opportunity to access the work in the formal sector. Also, the sector is also expanding against the economy, especially the family economy [2]. This kind of condition indicates that women have potential. The construction of stereotypes and marginalization of women developing in the community has made them not have the freedom to work in the formal sector. Labeling is often given to women who are considered to have diligent nature, so women are only charged in domestic work of households. 
Gender construction is not only contained in the environment and family but the context of the labor market. The gender ideology that created the meeting became the inferior people increasingly oppressed women in the economic sector. Labeling is attached to women that they are not a major contributor to the economy as a reason to give a cheap wage. In a capitalist economy puts women and men in different classes. The males are defined by the bourgeoisie and the woman as the proletariat [4].

This research is based on the results of several informant interviews in North Jakarta district, because this location is a dense and rundown village area that is very close to the factory industrial area and there is a homeworkers area that works as a shoe-pedestal (pengelem alas sepatu) of famous brands.

\section{Results and Discussion}

\subsection{The Role of Women homeworkers in Household}

Based on the findings of the data obtained by researchers in the field, a majority of homeworkers is dominated by vulnerable women. Vulnerable in the sense of having low education and does not have a high skill capacity (lower skill) to do the job in the formal sector. Also, homeworkers are chosen by women because they can do two jobs at the same time that they are doing domestic and productive work.

The two dominant theories regarding the division of household work show two different sides. There is an assumption that women are mostly only in the domestic domain while men are in the realm of paid work. On the other hand, there are those who emphasize that women have a dual role, namely as housewives and workers. This is what happened to the women homeworkers in Penjaringan district.

Women homeworkers must divide their time as housewives and as workers who do productive work at home. Although their work requires very intense time, women homeworkers must be responsible for the domestic work they are required to do. There is no division of household roles between men and women in the female household of homeworkers. In this case, women must do it. In the division of household roles as stated by Sweetman [5] regarding the role of men in carrying out domestic work and sharing roles in child care, this did not occur in the household life of shoe-footing homeworkers in Penjaringan.

\subsection{Wage Gap for Women Homeworkers}

The results of interviews and observations made by researchers, the phenomenon that occurred were that women homeworkers did not realize that she was a worker. Women homeworkers only assume that what they do is only side jobs that do not have a significant economic value for their household income. This is because they do it to fill their spare time at home. Homeworkers still define themselves as housewives. Even though what they have done so far is products that have commercial value and even become goods exported abroad.

Homeworkers take jobs through intermediaries. They cannot take it directly from the main employer (company). The unclear recruitment process leads to the absence of employment agreements between intermediaries with homeworkers or homeworkers with employers (companies) or agreements between intermediaries and employers (companies). They only work based on opportunities and trust between the two parties. 
The absence of a written agreement has caused the wage system for homeworkers to not match the minimum wage they should have received. Even in the process, homeworkers must buy their raw materials used such as glue and brush to the employer.

Because of very low wages, various difficulties must be experienced by women homeworkers who often force them to borrow money from employers. In one day, an average female homeworker only received 200 pairs of shoes. One pair of shoe pads valued by intermediaries is only Rp.400, - this value is the net price of an intermediary for a pair of shoes. The target work provided by the intermediary must be completed and returned at the latest at night. This means that the net income of a homeworker within a minimum of 12 hours only receives Rp.80,000. Whereas to complete the target of 200 pairs of footwear, women homeworkers must also complete their responsibilities as housewives in completing domestic work and taking care of children.

When wages are received compared to their daily expenses, it is certainly not sufficient. Nor can they demand much for a wage increase. Because there is no written statement requiring employers (companies) to provide wages by existing regulations relating to the minimum wage. So female home workers can only accept what is given by employers. For when they demanded a lot, then the stakes were that they would lose their work. Losing jobs for women homeworkers means they can no longer help provide additional income for families. This means the resilience of their families will be increasingly vulnerable in fulfilling their daily needs. When associated with Marx's capital theory, this is the consequences for those women homeworkers who are regarded as proletarian in the capital owner's economic system in this case the bourgeoisie (employer or company).

\section{Acknowledgements}

We would like to thank the University of Indonesia's Directorate of Research and Community Service for supporting this research. We are also thank the Trade Union Rights Centre (TURC) for giving us the opportunity to conduct research. In addition, we also thank to Mrs. Murhayati as Coordinator Women Homeworkers Jakarta and woman homeworkers "Pengelem Alas Sepatu" in the Penjaringan, North Jakarta who have been willing to take the time to provide information related to the research that we do.

\section{References}

[1] BPS, "Indonesia Dalam Angka 2018," 2018.

[2] S. Nazara, Ekonomi Informal di Indonesia: Ukuran, komposisi dan evolusi. Organisasi Perburuhan Internasional, 2016.

[3] Organisasi Perburuhan Internasional, "Pekerja Rumahan di Indonesia: Hasil dari Penelitian Pemetaan Pekerja Rumahan di Sumatera Utara, Jawa Barat, Jawa Tengah, Yogyakarta, Jawa Timur dan Banten," 2015.

[4] K. Marx and F. Engels, Keluarga Suci, Kritik atas Kritik yang Kritikal. 2005.

[5] C. Sweetman, Development and Poverty. Oxford, 2002. 